\title{
Two Polymorphic Crystal Structures of Cholesteryl 2,4-Dichlorobenzoate
}

\author{
Young Ja Park \\ Department of Chemistr: Sook Mung Women's Lniversity; Seoul 140-742, Korea \\ Received February 6, 2004
}

Key Words : Cholesteryl 2,4-dichlorobenzoate, Polyımorphs, Liquid crystal

Cholesterol derivalives are important constituents of pathological conditions such as atherosclerosis, the formation of thick deposits on the inner surfaces of blood vessels.' The crystal structures of cholesteryl 2,4-dichlorobenzoate are of interest because their mode of crystallization and packing might be useful in understanding their deposition in arteries.

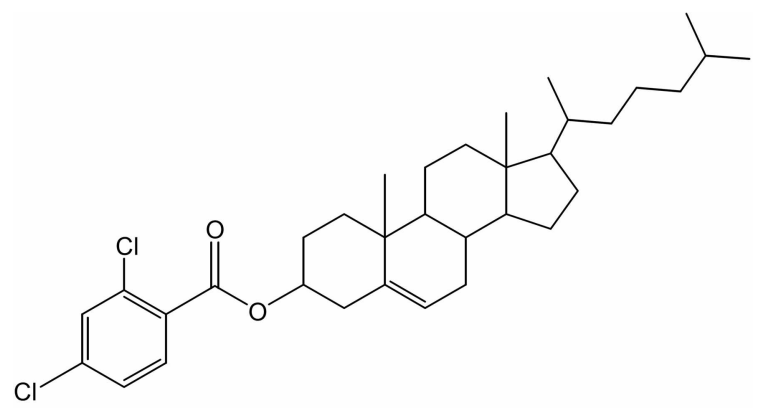

The cholesteryl 2,4-dichlorobenzoate $\left(\mathrm{C}_{34} \mathrm{H}_{48} \mathrm{O}_{2} \mathrm{Cl}_{2}\right)$, has been erystallized in two polymorphic forms. Both forms are orthorhombic, space group P2 2,2 , with form (1a) crystallizing from dichloromethane and form (1b) from hexane solution.

The molecular conformation is depicted in Figure 1 . The bond distances and angles of two molecules are constistent with those found in other other cholesterol derivatives. ${ }^{2-1(1}$ There are considerable differences in the conformations of

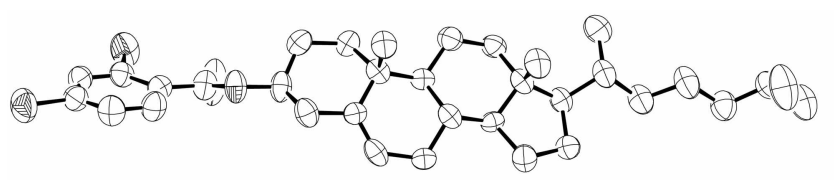

1a

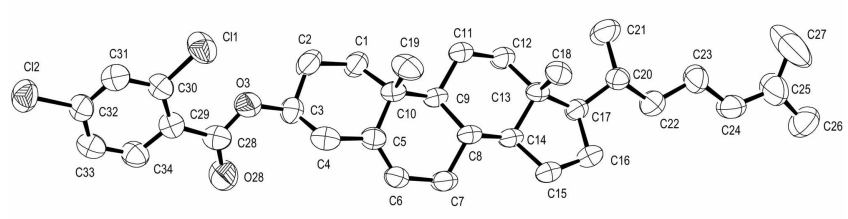

$1 \mathrm{~b}$

Figure 1. Vicw of the molccules of polymorph (1a) and polymorph (1b) showing the atomic numbering. Displacement ellipsoids are draws at dhe 50\% probability level and $\mathrm{H}$ aloms have been omilled for the sake of clarity.

e-mail: yjpark@ àsookmyung.ac.kr molecules 1a and $\mathbf{1 b}$ but not in the tetracyclic system. The major difference in the overall shape of the molecules can be attributed to the twist of the ester chains about the $\mathrm{C} 3-\mathrm{O} 3$ bond and $\mathrm{C} 28-\mathrm{C} 29$ bond. The torsion angles of $\mathrm{C} 2-\mathrm{C} 3-\mathrm{O} 3-$ $\mathrm{C} 28$ and $03-\mathrm{C} 28-\mathrm{C} 29-\mathrm{C} 30$ are $88.2(7)$ and $160.8(6)^{\circ}$ in molecule $\mathbf{l a}$ and $156.7(7)$ and $-10.7(11)^{\circ}$ in molecule $\mathbf{1 b}$, respectively. (Sec Table 1)

The packing diagrams for the wo polymorphs are shown in Figure 2. The erystal structures are quite different each other although both foms crystallize in $\mathrm{P} 22_{2} 2_{2}$, and their corresponding unit cell distances are in good agreement within the $1 \AA$. The polymorphism could modify molecular geometries, ${ }^{11.12}$ la and $\mathbf{1 b}$, which are the conformational isomers each other. These lead 10 different molecular packings. No solvent molecules of crystallization are observed in both crystals.

The erystal structure of la is remarkable in forming layer structures in which the ecntral region of the layers, composed largely of semi-rigid cholesteryl groups is closely packed, and the packing of dichlorobenzoate and the isoprenoid tail of the cholesterol form the interlace region between layers. The molecules are aligned antiparellel to form layers alternately. These layers are piled up in a herring-bone arrangements.

Crystals of 1 a melt to give an isotropic liquid (at $132.5^{\circ} \mathrm{C}$ ) with an intermediate cholesteric phase (at $130.8^{\circ} \mathrm{C}$ ). Such behavior secms consistent with the nature of the layer packing arrangement. which is dominated by the strong cholesteryl-cholesteryl interactions.

solid $\stackrel{130.8^{\circ} \mathrm{C}}{\longrightarrow}$ cholesteric phase $\stackrel{132.5^{\circ} \mathrm{C}}{\longrightarrow}$ isotropic liquid

The molecules of $\mathbf{1 b}$ adopt extended conformations along

Table 1. Comparison of selected torsion angles $\left({ }^{\circ}\right)$

\begin{tabular}{lcc}
\hline & $\mathbf{1 a}$ & $\mathbf{1 b}$ \\
\hline $\mathrm{C} 1-\mathrm{C} 2-\mathrm{C} 3-\mathrm{O} 3$ & $178.0(6)$ & $178.6(7)$ \\
$\mathrm{C} 5-\mathrm{C} 4-\mathrm{C} 3-\mathrm{O} 3$ & $-179.0(5)$ & $-171.0(5)$ \\
$\mathrm{C} 2-\mathrm{C} 3-\mathrm{O} 3-\mathrm{C} 28$ & $88.2(7)$ & $156.7(7)$ \\
$\mathrm{C} 4-\mathrm{C} 3-\mathrm{O} 3-\mathrm{C} 28$ & $-149.8(6)$ & $-82.5(8)$ \\
$\mathrm{C}-\mathrm{O} 3-\mathrm{C} 28-\mathrm{O} 28$ & $-3.0(12)$ & $7.7(12)$ \\
$\mathrm{C} 3-\mathrm{O} 3-\mathrm{C} 28-\mathrm{C} 29$ & $177.1(6)$ & $-172.0(6)$ \\
$\mathrm{O} 3-\mathrm{C} 28-\mathrm{C} 29-\mathrm{C} 30$ & $160.8(6)$ & $-10.7(11)$ \\
$\mathrm{O} 3-\mathrm{C} 28-\mathrm{C} 29-\mathrm{C} 34$ & $-23.2(9)$ & $165.6(7)$ \\
$\mathrm{O} 28-\mathrm{C} 28-\mathrm{C} 29-\mathrm{C} 30$ & $-19.1(12)$ & $169.6(7)$ \\
$\mathrm{O} 28-\mathrm{C} 28-\mathrm{C} 29-\mathrm{C} 34$ & $157.0(9)$ & $-14.1(11)$ \\
\hline
\end{tabular}




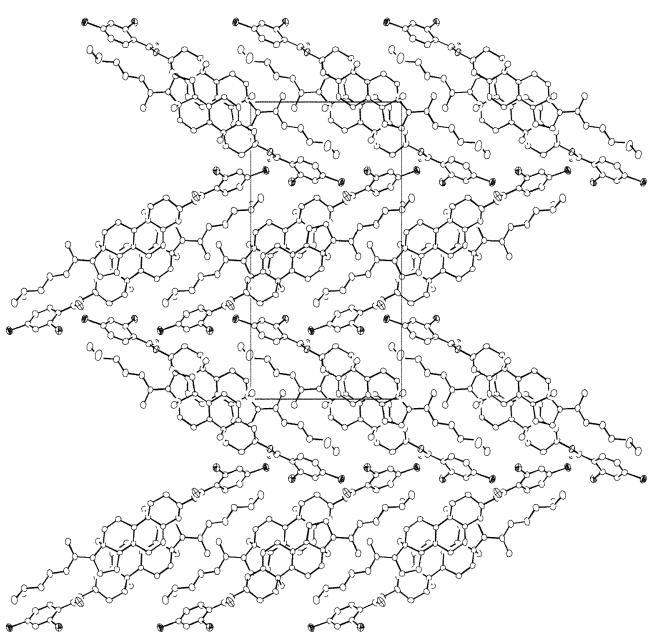

(a)

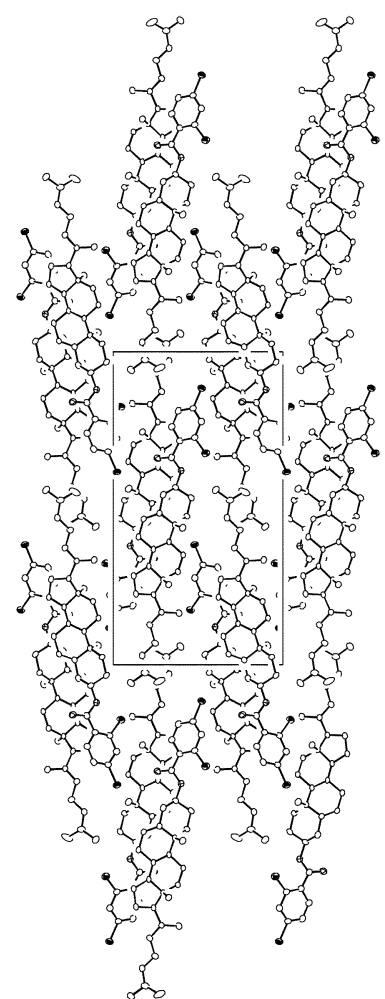

(b)

Figure 2. The erystal packing viewed down the $a$ axis for (a) polymorph (Ia) and (b) polymorph (1b). The $b$ axis is hori $s$ tal.

the $c$ axis and are orientated antiparallel, as shown in Figure 2(b). The plane of the tetracyclic rings and benzoate is parallel to $b c$ plane. There are the close-stacking of cholesteryl and benzoate rings, with the terminal isoprenoid tails overlapping partially. The molecules form no distinct layer structures.

Crystals of 1b melt at $133.7^{\circ} \mathrm{C}$ without any liquid crystalline state.

\section{Experimental Section}

The crystal of title compound was obtained from Tokyo Kasei Kogyo Co., LTD. The crystals la were obtained by recrystallization from dichloromethane and $\mathbf{1 b}$ from hexane at room temperature.

Crystals of 1a melt to give an isotropic liquid (at $132.5^{\circ} \mathrm{C}$ ) with an intermediate cholesteric phase (at $130.8^{\circ} \mathrm{C}$ ). Crystals of $\mathbf{1 b}$ melt at $133.7^{\circ} \mathrm{C}$. The measurements were made by using Differential Scanning Calorimeter (DSC 2910, TA Instruments).

X-ray data were collected using a Nonius CAD-4 diffractometer with $\operatorname{MoK} \alpha$ graphite monochromated radiation up to $\theta_{\text {Iriax }}$ of $25^{\circ}$. Space Group of both crystals is orthorhombic, $P 22_{1} 2_{2}$. The $\omega 2 \theta$ scan width was $(1.10$ $+0.35 \tan \theta)^{\circ}$.

Refinement was by full-matrix least-squares methods. All $\mathrm{H}$ atoms were located in geometrically calculated positions and refined isotropically. The following programs are used: Data collection: CAD-4-PC software. ${ }^{13}$ Cell refinement:
Table 2. Crystal data and structure refinements of sholesteryl 2.4dichlorobenzoate

\begin{tabular}{|c|c|c|}
\hline & 1a & 1b \\
\hline$a$ & $9.6209(15) \wedge$ & $9.2944(9)$ \\
\hline$b$ & $12.8168(12) \mathrm{A}$ & $13.4570(13)$ \\
\hline$c$ & $25.198(3) \mathrm{A}$ & $24.7277(17)$ \\
\hline Absorption coefficent & $0.238 \mathrm{~mm}^{-1}$ & 0.238 \\
\hline $\begin{array}{l}\text { Absorption conrection by psi- } \\
\text { scanss }{ }^{17} T_{\min } / T_{\max }\end{array}$ & 0.91330 .999 & 0.8720 .998 \\
\hline Number of measured rellections & 3097 & 3441 \\
\hline $\begin{array}{l}\text { Number of observed reflections } \\
{[1>2 \sigma(I)]}\end{array}$ & 2190 & $246 \mathrm{l}$ \\
\hline Number of relined parameters & 344 & 344 \\
\hline $\mathrm{R}\left(\mathrm{F}^{2}\right)$ & 0.056 & 0.068 \\
\hline Goodness-of-fit on $\mathrm{F}^{2}$ & 1.056 & 1.168 \\
\hline$\Delta \rho \max$ & $0.26 \mathrm{e} \AA^{3}$ & 0.35 \\
\hline$\Delta p m i n$ & $-0.23 e \lambda^{3}$ & -0.41 \\
\hline
\end{tabular}

SE $T 4^{1.3}$ and CELDIM, ${ }^{1.3}$ Data reduction: WinGX.1+ Program(s) used to solve structure: SHELXS-97. ${ }^{15}$ Program(s) used to refine structure: SHELXL-97, ${ }^{15}$ Molecular graphics: ORTEP3. If The crystal data and refinements were sumınarized in Table 2.

Supporting Information Materials. Crystallographic data for cholesteryl 2,4-dichlorobenzoate have been deposited at the Cambridge Crystallographic Data Centre and allocated the deposition numbers CCDC 230251 for 1a and 230252 for $1 \mathbf{b}$. 
Acknowledgements. This research was supported by the Sook Myung Women's University Research Grants, 2001.

\section{References}

1. Abrahamsson. S.: Dahlen. B.: Lofgren. H.: Pascher. I.: Sundell. S. In Shuchure of Biological Membrames: Abrahamsson. S.: Pascher. I.. Eds.: Plenum Press: New York and London. 1977: p 1.

2. Craven. B. M. Cholesterol Civstal Sinctite : Adducts and Esters in The Plnsical Chenistry of Lipids, Handbook of Lipid Research: Small, D. M.. Ed.: Plenlin Press: New York, 1986; Vol. 4, pp 149182 .

3. Chandross. R. J.: Bordner. J. Acta Cryst. 1978. B34. 2872.

4. Park. Y. J.: Craven. B. M. J. Korean Chent. Soc. 1981. 25. 131.

5. Suh, I.-H.: Ko, T.-S : Park. Y. J: Yoon. Y. K: Saenger W. Acta Cryst. 1988. CHA. 2163 .

6. Park. Y. J. Oh. J. H. Korean J. Crystallography 2000. 11. 84

7. Kim. M. H.: Park. Y. J.: Ahn. C. T. Bull Korean Chem. Soc 1989. 10. 177.

8. Yun. M. K.: Park. Y. J.: Shin. W. Craven. B. M. Bull. Korean
Chem. Soc. 1989, 10. 335.

9. Kang. B. K.: Chung. M. T.: Park. Y. J. Bull. Konem Chem. Soc. 1985. 6.333.

10. Socci. E. P. Farmer. B. L. Acta Cryt. 1995. C5]. 888.

11. Gladkikh. O. P. Masunov, A. E.; Leonidov, N. B.; Belsky. V. K. Polmorphism of 6-1 fethywacil in Cowlations. Transformations. and Ineractions in Organic Constal Chemisny, Jones, D. W: Katrusiak. A. Eds.: International Union of Crystallography. Onford University Press: New York. 1994: p 266.

12. Gastone. G. Molecules and Holecular Crnstals in Fundamentals of Crystallography Giacovazzo. C. Ed. Intemational Union of Crystallography: Oxford University Press: New York, 1992; p 465.

13. Enraf-Nonius. $C A D-4-P C$ Sofnume. Version 1.1: Enraf-Nonius: Delft. The Netherlands. 1992

14. Farrugia. L. J. J. Appl. Cnst 1999.32. 837.

15. Sheldrick, G. M. SHELIS and SHELX-97: Institute Fur Anorganishe Chemie. Der Universität Göttingen: Germany, 1997.

16. Burnett. M. N.; Johnson. C. K. ORTEP III: Oak Ridge National Lab.: Tennessess. U. S. A.. 1996.

17. North. A. C. T.: Philips. D. C.: Mattews. F. S. Acta Cnst 1968. A2+. 351 . 